\title{
Rebranding an Institution of Higher Education in Botswana
}

\author{
Rina Makgosa (Corresponding Author) \\ Department of Marketing, University of Botswana \\ Private Bag 00701, Gaborone, Botswana \\ E-mail:makgosa@mopipi.ub.bw \\ Boikanyo A. Molefhi \\ ABM University College \\ Private Bag 00331, Gaborone, Botswana \\ E-mail: b_molefhi@yahoo.com
}

Received: June 8, 2012 Accepted: June 22, 2012

doi:10.5296/ber.v2i2.1926 URL: http://dx.doi.org/10.5296/ber.v2i2.1926

\begin{abstract}
The issue of rebranding institutions of higher education has attracted little attention in scholarly publications. However, intense competition in the higher education market has forced institutions to modify elements of their brands. The current study seeks to shed light on the challenges of undertaking a rebranding exercise in an institution of higher education in Botswana, a context which is under researched. The purpose of the current study is to establish the perceptions of students of the University of Botswana regarding its brand equity following the rebranding exercise. A structured questionnaire was administered to a sample of 336 University students majoring in business. Overall, the results showed that the brand equity of the new logo was lower than that of the old logo. The results of the paired t-tests revealed that students tend to recall and recognize the old logo more than the new logo. Students are also attracted, affectionate and attached to the old logo more than the new one. Since rebranding can erode some of the important aspects of an existing brand, it has to be implemented cautiously. Importantly, effective communication is critical to inspire students to embrace the new logo and their perceptions need to be tracked periodically in order to establish whether the desired brand image has been generated.
\end{abstract}

Keywords: Brand equity, Botswana, Higher education, Rebranding, University of Botswana 


\section{Introduction}

Rebranding refers to a process of giving an existing brand another name, term, sign, symbol, design, or a combination of brand elements, intended to identify the value provided by an institution of higher education and to differentiate it from competitors (Judson, Aurand, Gorchels, \& Gordon, 2009). An institution of higher education may rebrand itself to signal to the key target markets that it has modified its strategic focus (Stuart \& Muzellec, 2004) and to keep abreast with the challenge of an increasingly competitive and dynamic educational environment (Judson, et al., 2009). Rebranding could also be undertaken when the current brand is no longer relevant (Singh \& Dharanveer, 2011) and does not result in customer loyalty, acquisition of new clients, or the desired brand image (Melewar \& Akel, 2005).

Effective branding in institutions of higher education requires a critical understanding of the perceptions of the key target markets such as students, employees, employers, alumni, donors and the general public (Pesch, Calhoun, Schneider, \& Bristow, 2008). Although considerable research has been done on branding in institutions of higher education (Argenti, 2000; Chapleo, 2007; Judson, et al., 2009; Marrs, Gajos, \& Pinar, 2011; Melewar \& Akel, 2005; Pesch, et al., 2008), published research based on Sub-Sahara Africa and Botswana in particular is relatively limited. However, institutions of higher education in Botswana operate in an increasingly competitive educational environment and need to meet the needs of the direct and primary consumers of education better than their competitors. For example, in a bid to stay relevant, especially with intense competition from newly established privately-owned tertiary institutions, the University of Botswana decided to modify its logo, symbols and corporate colors in 2008 (Morewagae, 2008; Nkoga, 2008).

Thus, in order to improve the cumulative body of literature on branding in institutions of higher education, the primary focus of the current study is to identify the perceptions of students about the impact of rebranding on the brand equity of an institution of higher education. Specifically, the objectives of the current study are to (1) compare perceptions of students about the brand equity of the University of Botswana between the old and new logo, and (2) assess the effects of brand equity on overall attitude towards the new University of Botswana logo.

\section{Literature Review}

\subsection{Customer-Based Brand Equity}

The concept of customer-based brand equity has provoked various definitions (See, Aaker, 1991; Netemeyer, Krishnan, Pullig, Wang, Yagci, Dean, Ricks \& Wirth, 2004; Yoo \& Donthu, 2001). According to Keller (1993), customer-based brand equity is the differential effect of brand knowledge on a consumer's response to the marketing of the brand which occurs when a consumer is familiar with the brand and holds strong brand associations. This definition gives insight into how consumers select and choose a brand (Netemeyer, et al., 2004). It also enables marketers to suggest unique programs for marketing a brand, evaluate how consumers respond to the marketing of a brand and how marketing efforts improve the value of the brand (Keller, 1993). Within the context of institutions of higher education, 
customer-based brand equity is concerned with the way prospective students, alumni, legislators, donors, employees, employers and the general public (i) perceive the value added to an institution by associating it with a brand name and (ii) their response to the marketing of an institution's brand.

Customer-based brand equity is a multidimensional construct. According to Washburn and Plank (2002) customer-based brand equity is described as comprising three dimensions consumer knowledge, familiarity, and associations with respect to the brand. Based on the fact that brand knowledge is central to the definition of customer-based brand equity, it was further defined on the basis of brand awareness and brand image (Keller, 1993). Additionally, brand awareness was sub-divided into brand recall and recognition which signifies familiarity and commitment while brand image is represented by the brand associations held in consumer memory. Aaker (1991) suggested that customer-based brand equity comprises five dimensions: brand loyalty, brand awareness, perceived quality, brand associations, and other proprietary brand assets, such as trademarks and patents. Keller and Lehmann (2003) proposed five dimensions of customer based brand equity: brand awareness, associations, attitudes, attachment, and activity. Yoo and Donthu (2001) also suggested that collectively customer based brand equity is based on brand awareness, brand loyalty, brand associations and perceived quality.

Although many dimensions of customer-based brand equity have been offered in the literature, the main focus was on commercial businesses rather than higher education (Keller \& Lehmann, 2003; Netemeyer et al., 2004; Yoo \& Donthu, 2001). Thus, the conceptualization of customer-based brand equity in the current study is based on the commonly proposed dimensions of brand equity: brand awareness, associations and loyalty. Brand awareness is the ability for a consumer to recognize and recall a brand (Aaker, 1991; Keller, 1993). Within the context of the current study, brand awareness is the ability of the students to recognize and recall the brand following the rebranding exercise. Brand associations have been defined as the strength of the brand in a consumer's memory that manifests in the form of meanings that consumers ascribe to the brand (Keller, 1993). Here, the term 'brand associations' refers to the ability of the students to ascribe meanings to the brand following the rebranding exercise. Brand loyalty refers to the attachment that a customer has to a brand (Aaker, 1991). In the current study, brand loyalty refers to the tendency of the students to be attached to the brand, following a rebranding exercise. The conceptualization of brand equity in the current study is similar to the study by Teh and Salleh (2011) who argued that when Keller (1993)'s conceptualization of brand equity is merged with Aaker (1991)'s, three dimensions are produced, namely brand loyalty, brand awareness and perceived quality.

\subsection{Branding in Institutions of Higher Education}

There is a general consensus among scholars that branding is as important in educational institutions as it is in commercial businesses (Gopalan, Pagiavalas \& Jones, 2008; Pesch, et al., 2008). Branding provides an institution identity and differentiates it from other competitors (Curtis, Abratt, \& Minor, 2009; Gupta \& Singh, 2010; Judson, et al., 2009). 
Specifically, a strong brand increases an institution's ability to compete for the best students, gain alumni membership and support and financial support from donors (Judson, et al., 2009). From the students' view point, branding serves as a promise to meet their expectations and facilitates decisions relating to the selection of which institution to attend (Gupta \& Singh, 2010). Branding is also more critical for higher education institutions, since education as a product is experiential, intangible and its perceived value is difficult to assess prior to consumption (Gopalan, et al., 2008; Lowrie, 2007; Nicholls, Harris, Morgan, Clarke, \& Sims, 1995).

A growing number of published studies have demonstrated the remarkable application of branding in institutions of higher education. In a study based on South African business schools, competence emerged as the most communicated brand personality dimensions in the schools' websites while sophistication was the least communicated (Opoku, Abratt \& Pitt, 2006). An investigation of brand strength, favorability and uniqueness on brand equity in Malaysia revealed that the effects of brand strength and favorability on brand equity were higher in private institutions while brand uniqueness was a strong predictor of brand equity for public institutions (Teh \& Salleh, 2011). Sharaai and Areni (2009) found that business schools associated with highly-ranked, prestigious universities such as Manchester Business School, Harvard Business School, and Stanford Graduate School of Business portrayed the university brand either solely or in conjunction with a less prominent school brand. However, business schools associated with less prestigious universities or not associated with any university featured their school brand. In the case of Embry-Riddle Aeronautical University in United States, the administration of the website, marketing of the program and positioning of the corporate brand were significantly addressed in the process of managing the institution brand (Curtis, et al., 2009). Melewar and Akel, (2005) noted that the reputation of being an innovative and radical institution was not captured in the University of Warwick's corporate visual identity and there was lack of consistency across departments.

Numerous challenges in the educational environment have increased the emphasis placed on branding of institutions of higher education. In particular, the decline of students' enrolment, increased competition, and decreases in government funding have forced institutions of higher education to exploit marketing strategies for achieving competitive advantage and ensuring customer satisfaction, (Curtis, et al., 2009; Judson, et al., 2009). The dynamics of globalization such as privatization, diversification, decentralization, and internationalization of education have also fuelled competitiveness in higher education institutions (Gopalan, et al., 2008; Gupta \& Singh, 2010). Consequently, success in the educational marketing environment depends on the ability of an institution to recruit and retain the best students, faculty and staff (Jevons, 2006; Melewar \& Akel, 2005) and to provide students with challenging and quality education that will enable them to pursue productive careers (Pesch, et al., 2008). Institutions also need to build and maintain widespread public and legislative support, and keep a loyal and close connection with alumni and donors (Judson, et al., 2009). To achieve this, it is imperative for higher education institutions to create a consistent, powerful brand identity that provides them with a competitive advantage (Gopalan, et al., 2008). 
However, the concept of branding as applied to education institutions is different from branding in the commercial sector (Gupta \& Singh, 2010). In particular, it is about who the university is and what it stands for rather than what a particular product offers to the market place. Argenti (2000) cautioned that conventional branding techniques alone are not suitable in the education market because of the greater scrutiny from customers and internal resistance from non-business oriented faculties. Similarly, internal factors such as lack of understanding of branding, variance in the roles of executives in brand management, lack of acceptance of branding concepts by non-business faculties, sub-brands being emphasized by faculties, and lack of a clear brand principle limit the application of branding in educational institutions (Chapleo, 2007). Furthermore, institutions of higher education have been criticized for lacking relevance (Lowrie, 2007) as a majority of graduates fail to secure employment and rarely exhibit entrepreneurial skills by initiating their own business ventures after completing their studies. There is also a growing concern that scarce financial resources are diverted to branding programs as opposed to teaching and research activities (Gopalan, et al., 2008). These challenges provide credence for investigating how students perceive educational institution brands as it will signal whether the intended purpose of meeting the needs of the primary consumers through branding is achieved.

Although, the research of branding in institutions of higher education is notable, a substantial number of published studies discuss the subject conceptually (Argenti, 2000; Gupta \& Singh, 2010; Jevons; 2006; Nicholls, et al., 1995). Among the available empirical studies, the concentration is on branding initiatives in institutions of higher education in United States (Curtis, et al., 2009; Judson, et al., 2009; Pesch, et al., 2008) and United Kingdom (Chapleo, 2007; Melewar \& Akel. 2005). In the United States, university branding management is of great concern (Jevons, 2006) and universities are ahead of those in the United Kingdom in terms of embracing the concept of branding (Chapleo, 2007). In Asia, however, academic interest in higher education branding is only a recent phenomenon (Teh \& Salleh, 2011), as is the case in South Africa, where higher education branding has received limited academic attention (Opoku, et al., 2006). The current study contributes to the body of knowledge on higher education branding by empirically investigating the perceptions of students in a national university in Botswana about the brand following a rebranding exercise. This will help to isolate the consequences of rebranding by demonstrating how a change of the logo of the university affects brand equity and overall attitudes.

\subsection{Rebranding in Institutions of Higher Education}

Academic research relating to rebranding emphasizes the effective ways of ensuring rebranding in commercial enterprises (Merrilees \& Miller, 2008; Muzellec \& Lambkin, 2006; Singh \& Dharamveer, 2011) rather than institutions of higher education. Muzellec and Lambkin (2006) described rebranding as a continuum ranging from evolutionary to revolutionary rebranding. Evolutionary rebranding represents a change in only one of the elements of a brand while revolutionary branding signifies a change in all the elements of a brand simultaneously (Stuart \& Muzellec, 2004). Rebranding occurs under several circumstances such as change in the market place, change in products, change in brand image, and during acquisitions or mergers (Singh \& Dharamveer, 2011). The most 
compelling reason for undertaking a rebranding exercise is acquisitions or mergers (Muzellec \& Lambkin, 2006) because old elements of a brand are usually inappropriate (Stuart \& Muzellec, 2004).

Although rebranding may communicate an updated identity, it may phase out some of the attributes associated with the original brand, which may have an inverse effect on the brand's image. Rebranding is costly and has a high level of reputation risk because it can potentially nullify years of effort in creating awareness and building the brand image (Muzellec \& Lambkin, 2006). Rebranding also opposes the standard marketing practice which proposes that maintaining strong brands over a long time and consistently supporting them will result in sales (Stuart \& Muzellec, 2004). For instance, consumers who were strongly committed to a brand perceived logo redesign negatively and had lower brand attitudes (Walsh, Winterich \& Mittal, 2010). Additionally, rebranding commands extensive planning and sometimes organizations do not engage fully in the exercise (Singh \& Dharamveer, 2011). It is generally held that successful rebranding requires extensive research; the support and commitment of the leadership; involvement of all the levels of the organization; communication to ensure the understanding of the reason behind the change and evaluation after the brand launch (Merrilees \& Miller, 2008; Singh \& Dharamveer, 2011; Stuart \& Muzellec, 2004). Building and maintaining brands after rebranding also requires promotional resources yet the marketing budget of institutions of higher education is constrained (Judson et al., 2009).

The University of Botswana is a national university that was established in 1982. Although for years the University of Botswana has operated as the only university in the country, the establishment of private institutions such as ABM University College, Botswana Accountancy College, BA ISAGO University College and Limkokwing College of Creative Technology and Arts inspired changes in the higher education market environment. In a bid to keep abreast with intensifying competition in the higher education market, the University of Botswana decided to modify its logo, symbols and corporate colors. The original University of Botswana logo comprised of three key symbols: a cow's head which symbolized strength and depicted the history of "One Man, One Beast", sorghum leaves which symbolized growth and a book which symbolized learning. After the rebranding exercise in 2008, the cow's head was replaced with a symbol of a shield or horns which still coveys the meaning of the "One Man, One Beast" concept. However, the sorghum leaves and the slogan of "Thuto ke Thebe" which means "education is a shield" still remained. Additionally, corporate colors were changed from burgundy and cream to lime green and blue representing the rain and agriculture that are essential to life (Morewagae, 2008; Nkoga, 2008).

\section{Methodology}

A survey research design using a structured questionnaire was used to investigate the perceptions of consumers about the University of Botswana brand following a rebranding exercise. The choice of this design is consistent with previous studies on higher education branding (Judson, et al., 2009, Pesch, et al., 2008) while other studies were either conceptually based (Argenti, 2000; Jevons, 2006; Gupta \& Singh, 2010) or based on a 
qualitative methodology (Chapleo, 2007; Curtis, et al., 2009; Lowrie, 2007; Melewar \& Akel, 2005). Harvey (1996) identified four groups who benefit from higher education: students, parents, institution authorities, and the general public. The current study focused on students as the direct and primary customers for higher education services (Gupta \& Singh, 2010). According to Pesch, et al. (2008) the key to successful implementation and adoption of a customer orientation in the branding of an education institution requires the assessment of students' perceptions of the institution's brand equity. In particular, a convenience sample of 336 University of Botswana students majoring in business was achieved. A convenience sample of business students was used as they are formally taught about marketing and branding and thus are more likely to be more expressive as far as branding is concerned.

Data for the main survey was collected by way of a structured questionnaire that was pre-tested to check for clarity and accuracy. The questionnaires were hand distributed to students around the faculty building and were completed in the presence of the interviewer. The questionnaire consisted of nineteen (19) items relating to the three dimensions of brand equity: brand awareness, brand association and brand loyalty. The eight (8) items used to measure brand awareness were adopted from Aaker (1991) and Yoo \& Donthu (2001). Six (6) items which were adapted from Aaker (1991) and Yoo \& Donthu (2001) were used as measures for brand association. Loyalty was measured using five (5) items adopted from Yoo \& Donthu (2001). Respondents were required to indicate a degree of agreement with each item using the 5 point Likert scale for each item for each of the logos. The other question was a single question about overall attitude towards the University of Botswana following the rebranding exercise. Questions on age and gender were also included.

\section{Data Analysis and Findings}

After attaining 336 useable responses, data obtained from the questionnaires was analyzed using frequency analysis, exploratory factor analysis, paired t-tests and regression in SPSS. The frequency analysis for the respondent profile is given in Table 1.

Table 1. Respondents' Profile

\begin{tabular}{|l|c|c|}
\hline Characteristics & Frequency & Percentage \\
\hline Gender & & \\
\hline Male & 154 & 45.8 \\
\hline Female & 182 & 54.2 \\
\hline Total & 336 & 100 \\
\hline Age & & \\
\hline Less than 18years & 14 & 4.2 \\
\hline $18-25$ years & 272 & 81 \\
\hline 26-35 years & 33 & 9.8 \\
\hline $36-45$ years & 15 & 4.5 \\
\hline 46 years + & 2 & 0.6 \\
\hline Total & 336 & 100 \\
\hline
\end{tabular}

An analysis of the demographic profile of the respondents presented in Table 1 reveals that a 
majority of the respondents were females and were in the age group 18 and 25 years.

\subsection{Dimensions of Brand Equity between the Old Logo and New Logo}

In order to compare perceptions of brand equity between the old and new logo, two separate exploratory factor analysis were conducted for each logo. The primary goal of the exploratory factor analysis was to identify the key dimensions of brand equity for the University of Botswana using the current data. In conducting the exploratory factor analysis, the Principal components method was used, with eigen values set to be greater than 1 with a rotation method of Varimax. The data was sorted by size and coefficients less than .4 were suppressed. Then, Cronbach Alpha was used to assess the reliability of the key dimensions of brand equity that emerged between the two logos. The results of the exploratory factor analysis and reliability analysis using Cronbach Alpha are depicted in Table 2.

Table 2. Factor analysis of Brand Equity for the University of Botswana before and after Rebranding $(\mathrm{n}=336)$

\begin{tabular}{|c|c|c|c|c|}
\hline & \multicolumn{2}{|c|}{$\begin{array}{c}\text { Before Rebranding } \\
\text { (Old Logo) }\end{array}$} & \multicolumn{2}{|c|}{$\begin{array}{l}\text { After Rebranding } \\
\text { (New Logo) }\end{array}$} \\
\hline & \multirow[t]{2}{*}{$\begin{array}{l}\text { Factor } \\
\text { Loading }\end{array}$} & \multirow{2}{*}{$\begin{array}{l}\text { \% of } \\
\text { variance } \\
\text { Alpha }(\alpha)\end{array}$} & \multirow[t]{2}{*}{$\begin{array}{l}\text { Factor } \\
\text { Loading }\end{array}$} & $\begin{array}{l}\text { \% of } \\
\text { variance }\end{array}$ \\
\hline & & & & Alpha $(\alpha)$ \\
\hline \multirow[t]{2}{*}{ Factor 1: Brand Image } & & 59.66 & & 59.05 \\
\hline & & $\alpha=.96$ & & $\alpha=.96$ \\
\hline I am attracted to this logo & .86 & & .85 & \\
\hline I am attached to this logo & .85 & & .87 & \\
\hline I have a lot of affection for this logo & .85 & & .89 & \\
\hline I would love to recommend this logo & .82 & & .80 & \\
\hline $\begin{array}{l}\text { Thinking about this logo brings me a } \\
\text { lot of joy and pleasure }\end{array}$ & .82 & & .82 & \\
\hline $\begin{array}{l}\text { I will not consider any other logo but } \\
\text { this one }\end{array}$ & .82 & & .76 & \\
\hline This logo would be my first choice & .80 & & .75 & \\
\hline This logo expresses my personality & .79 & & .81 & \\
\hline $\begin{array}{l}\text { This logo increases the respectability } \\
\text { of the students }\end{array}$ & .76 & & .76 & \\
\hline I consider myself loyal to this logo & .71 & & .69 & \\
\hline $\begin{array}{l}\text { This logo is unique when compared to } \\
\text { other competing ones }\end{array}$ & .52 & & Factor 2 & \\
\hline I like and trust this logo & $\mathrm{N} / \mathrm{A}$ & & .67 & \\
\hline \multirow[t]{2}{*}{ Factor 2 - Brand Awareness } & & 9.69 & & 9.02 \\
\hline & & $\alpha=.88$ & & $\alpha=.84$ \\
\hline $\begin{array}{l}\text { I can recognize this logo quickly } \\
\text { among competing ones }\end{array}$ & .82 & & .83 & \\
\hline I am familiar with this logo & .79 & & .80 & \\
\hline
\end{tabular}




\begin{tabular}{|c|c|c|}
\hline $\begin{array}{l}\text { Some characteristics of this logo } \\
\text { come to mind quickly }\end{array}$ & .76 & .66 \\
\hline I know what this logo stands for & .71 & .55 \\
\hline $\begin{array}{l}\text { Some characteristics of this logo } \\
\text { come to mind quickly when I see it. }\end{array}$ & .69 & .52 \\
\hline $\begin{array}{l}\text { When I think of tertiary institutions, } \\
\text { this logo comes to mind. }\end{array}$ & .66 & .68 \\
\hline I can quickly recall this logo & .63 & N/A \\
\hline $\begin{array}{l}\text { This logo is unique compared when } \\
\text { compared with to other competing } \\
\text { ones }\end{array}$ & Factor 1 & .64 \\
\hline
\end{tabular}

Table 2 indicates that two dimensions of brand equity emerged for both the old and new logo. Eighteen out of nineteen items were retained for the old logo and the total variance explained by the two dimensions is $69.36 \%$. The item 'I like and trust this logo' was deleted as it loaded equally in both dimensions. Just as in the case of the old logo, eighteen out of nineteen items were retained and the total variance explained by the two dimensions is $68.07 \%$. The item ' $I$ can recall this logo quickly' was deleted as it achieved a very weak factor loading."-The two dimensions for both the old and new logo were labeled as follows: Factor 1: Brand image which includes affection, attraction, attachment, loyalty, trust, and preference. Factor 2: Brand Awareness covers familiarity, knowledge, recall and recognition, all of which relate to an individual's thought process and intellectual activity. Although a total of eighteen items of brand equity were retained under both the old and new logo, the item 'this logo is unique when compared with other competing ones' loaded under the brand image dimension for the old logo while for the new logo the item loaded under the brand awareness. In addition, the Alpha coefficients for brand image and brand awareness for both the old and new logo achieved higher reliability coefficients.

\subsection{Perceptions of Brand Equity between the Old Logo and New Logo}

In order to identify significant differences in the perceptions of brand equity between the old and new logo firstly, Paired t-tests were used (Table 3).

Table 3. A Comparison of Consumer Perceptions of Brand Equity after Rebranding

\begin{tabular}{|l|l|l|l|l|}
\hline & $\begin{array}{c}\text { Old Logo } \\
\text { Mean (SD) }\end{array}$ & $\begin{array}{c}\text { New Logo } \\
\text { Means (SD) }\end{array}$ & t & Sig \\
\hline Factor 1: Brand Image & & & & \\
\hline I am attracted to this logo & $3.45(1.41)$ & $3.01(1.36)$ & 3.45 & .001 \\
\hline $\begin{array}{l}\text { Thinking about this logo brings me a lot of } \\
\text { joy and pleasure }\end{array}$ & $3.47(1.46)$ & $2.81(1.32)$ & 5.57 & .001 \\
\hline I have a lot of affection for this logo & $3.48(1.42)$ & $2.90(1.34)$ & 4.77 & .001 \\
\hline I will not consider any other logo but this one & $3.49(1.41)$ & $2.88(1.32)$ & 5.01 & .001 \\
\hline I am attached to this logo & $3.43(1.42)$ & $2.87(1.32)$ & 4.67 & .001 \\
\hline I would love to recommend this logo & $3.66(1.38)$ & $3.06(1.36)$ & 4.61 & .001 \\
\hline This logo would be my first choice & $3.66(1.46)$ & $3.01(1.37)$ & 4.75 & .001 \\
\hline
\end{tabular}




\begin{tabular}{|l|l|l|l|l|}
\hline This logo expresses my personality & $3.26(1.39)$ & $2.82(1.32)$ & 4.01 & .001 \\
\hline $\begin{array}{l}\text { This logo increases the respectability of the } \\
\text { students }\end{array}$ & $3.73(1.24)$ & $3.09(1.23)$ & 5.70 & .001 \\
\hline I consider myself loyal to this logo & $3.72(1.29)$ & $3.13(1.30)$ & 5.04 & .001 \\
\hline Factor 2 Brand Awareness & & & & \\
\hline $\begin{array}{l}\text { Some characteristics of this logo come to } \\
\text { mind quickly }\end{array}$ & $4.18(1.14)$ & $3.13(1.35)$ & 9.71 & .001 \\
\hline $\begin{array}{l}\text { I can recognize this logo quickly among } \\
\text { competing ones }\end{array}$ & $4.22(1.07)$ & $4.02(1.17)$ & 2.24 & .026 \\
\hline I know what this logo stands for & $4.02(1.23)$ & $2.81(1.42)$ & 11.34 & .001 \\
\hline $\begin{array}{l}\text { Some characteristics of University of } \\
\text { Botswana come to mind quickly when I see } \\
\text { this logo }\end{array}$ & $4.14(1.09)$ & $3.08(1.29)$ & 4.62 & .001 \\
\hline I am familiar with this logo & $4.40(1.08)$ & $4.21(1.17)$ & 2.12 & .035 \\
\hline $\begin{array}{l}\text { When I think of tertiary institutions, this logo } \\
\text { comes to mind }\end{array}$ & $3.92(1.23)$ & $3.41(1.34)$ & 10.49 & .001 \\
\hline
\end{tabular}

The results of a series of paired t-tests depicted in Table 3 reveal that there is a significant difference in perceptions of brand equity between the old and new logo. In particular, the old logo achieved higher brand image and brand awareness than the new logo.

When using the dimension of Brand image as a basis for comparison, it is clear that the means of the old logo are higher than that of the new logo for the ten items. In fact, the means of the old logo ranged from 3.26 to 3.73 while for the new logo the means ranged from 2.81 to 3.13. However, two items 'I consider myself loyal to this logo' and 'this logo increases the respectability of students' achieved the two highest means for both the old logo and new logo. The two lowest means for the new logo were for the following two items 'this logo expresses my personality' and 'thinking about this logo brings me a lot of joy and pleasure'. When comparing both logos based on Brand Awareness, the old logo scored the highest means. In fact, means ranged from 3.92 to 4.40 for the old logo while the means for the new logo ranged from 2.81 to 4.21 . Overall, the means of brand awareness for both logos were higher than that of the brand image. The two highest means for both the old and the new logo were for the following items: 'I am familiar with this logo' and 'I can recognize this logo quickly among competing ones'. Nonetheless, the lowest mean was for the item 'I know what this logo stands for'.

Secondly, to assess the role of brand equity on overall attitudes towards University of Botswana after the rebranding exercise, regression (Enter method) was used. All the sixteen items of brand equity for the new logo were used as predictors (independent variables). The only significant and positive effect was found for knowledge of the new logo $(\beta=.23, \mathrm{t}=$ $3.18, \mathrm{p}=.002)$. The results suggest that the students who had more knowledge about the new logo were more likely to depict positive attitudes about the University of Botswana after the rebranding exercise. 


\section{Discussion and Conclusion}

The results have shown that the brand equity of both the old and new logo in the University of Botswana is adequately represented by two dimensions: brand image and brand awareness. These findings correspond to selected previous studies that have recommended varied dimensions of brand equity in commercial enterprises (Aaker, 1991; Keller, 1993; Keller \& Lehmann, 2003; Washburn \& Plank, 2002). This is also consistent with an observation made by Gupta and Singh (2010) who proposed that branding in commercial businesses could differ from branding in higher education. The results also showed that students believe that the old logo has more brand awareness than the new logo. Students were also more loyal, attached and affectionate to the old logo than the new logo. Thus, the branding equity of the University of Botswana brand has declined following a rebranding exercise. The findings correspond to assertions made by Muzellec and Lambkin (2006) who suggested that even though rebranding may positively affect a firm's reputation, it may also diminish some of the desired attributes associated with the brand. Furthermore, fewer students were knowledgeable about the new brand and those who were knowledgeable about the logo were likely to have a positive attitude about the University of Botswana. This corresponds with previous studies that have cautioned that it might take a long time for a new brand to yield the desired brand image (Singh \& Dharamveer, 2011; Stuart \& Muzellec, 2004).

The results of the current study add to the under researched area of rebranding in institutions of higher education by bringing a perspective from Botswana. Based on these findings it is recommended that the institution should continue to communicate with students in order to increase the ownership and acceptance of the new logo. Messages aimed at students should explain what the new logo stands for and the rationale for the change of logo. This could be done through conducting awareness campaigns around campus for each faculty and also including the background of the institution as well as explanation of the new brand as part of the orientation program for first year students. Similarly, the new logo scored the lowest means in terms of brand image. Thus the management of the University of Botswana should look into possible ways of making this logo more appealing and attractive and linking it to students' personalities thereby making them more attached to it. This can be achieved by designing a positioning message that clearly communicates the unique features of the University of Botswana compared to other educational institutions. As the marketing budget of universities is relatively constrained messages portraying the brand personality of the institution can be posted on the institution's website, print media and social media.

However, as in most research studies, this study is not without limitations. In conducting this research, the sampling method was non-probabilistic; therefore the respondents used in this study might not necessarily be representative of the population. In addition, in the future a more comprehensive study could also include other important key target markets such as the employees, the alumni, employers and the general public.

\section{References}

Aaker, D. A. (1991). Managing brand equity, New York: The Free Press. 
Argenti, P. (2000). Branding B-schools: reputation management for MBA programs, Corporate Reputation Review, 3(2), 171-178.

Chapleo, C. (2007). Barriers of brand building in UK Universities, International Journal of Nonprofit and Voluntary Sector Marketing, 12(1), 23-32. http://dx.doi.org/10.1002/nvsm.271

Curtis, T., Abratt, R., \& Minor, W. (2009). Corporate brand management in higher education: the Case of ERAU, Journal of Product and Brand Management, 18(6), 404-413. http://dx.doi.org/10.1108/10610420910989721.

Harvey, J. A. (1996). Marketing schools and consumer choice, The International Journal of Educational Management, 10 (4), 26-38.

Gopalan, S., Pagiavalas, N., \& Jones, T. (2008). Branding MBA programs: Are they sufficiently related to an institution's strategy? Proceedings of the Academy of strategic Management, Allied Academies International Conference, 7 (20), 14-19.

Gupta, M. \& Singh, P. B. (2010). Marketing and branding higher education: Issues and challenges, Review of Business Research, 10 (1), 46-53.

Jevons, C. (2006). Universities: a prime example of branding going wrong, Journal of $\begin{array}{llll}\text { Product and } \quad \text { Brand } & \text { Management, } & \text { 466-467. }\end{array}$ http://dx.doi.org/10.1108/10610420610712856.

Judson, K. M., Aurand, T. W., Gorchels, L., \& Gordon, G. L. (2009). Building a university brand from within: university administrators' perspectives of internal branding, Services Marketing Quarterly, 30 (1), 54-68. http://dx.doi.org/10.1080/1533296082467722.

Keller, K.L. (1993). Conceptualizing, measuring and managing customer-based brand equity, Journal of Marketing, 57 (1), 1-22.

Keller, K. L., \& Lehmann, D. (2003). How Do Brands Create Value, Marketing Management, 12 (3), 26-31.

Lowrie, A. (2007). Branding higher education: equivalence and difference in developing identity, Journal of Business Research, 60(9), 990-999. http://dx.doi.org/10.1016/j.jbusres.2007.01.024.

Marrs, M. K., Gajos, R., \& Pinar, M. (2011). Utilizing brand audit to develop university brand: A case study, Proceedings ASBBS Annual Conference: Las Vegas, February, 964-975.

Melewar, T.C. \& Akel, S. (2005). The role of corporate identity in the higher education sector: A case study, Corporate Communications: An International Journal, 10(1), 41-57. http://dx.doi.org/10.1108/13563280510578196.

Merrilees, B. \& Miller, D. (2008). Principles of corporate rebranding, European Journal of Marketing, 42 (5/6), 537-552.

Morewagae, I., (2008,), UB launches new look logo. [Online] Available: http://www.mmegi.bw (August 8, 2008). 
Muzellec, L. \& Lambkin, M. C. (2006). Corporate rebranding: the art of destroying, transferring and recreating brand equity? European Journal of Marketing, 40 (7/8), 803-824.

Netemeyer, R.G., Krishnan, B., Pullig, C., Wang, G., Yagci, M., Dean, D., Ricks, J., and Wirth, F. (2004). Developing and validating measures of facets of customer based brand equity, Journal of Business Research, 57 (2), 209-224.

Nkoga, G. (2008). UB Launches New Brand. [Online] Available: http://www.gazettebw.com (August 12, 2008).

Nicholls, J., Harris, J., Morgan, E., Clarke, K., \& Sims, D (1995). Marketing higher education: the MBA experience, International Journal of Educational Management, 9 (2), 31-38.

Opoku, R., Abratt, R., \& Pitt, L. (2006). Communicating brand personality: Are the websites doing the talking for the top South African business schools? Journal of Brand Management, $14(1 / 2), 20-39$.

Pesch, M., Calhoun, R., Schneider, K., \& Bristow, D. (2008). The student orientation of a college of business: An empirical look from the student perspective, Marketing Management Journal, Spring, 100-108.

Sharaai, Z.H. \& Areni, C (2009). Brand architecture for business Schools: Is the university or Benefactor the brand?" in Sustainable Management and Marketing Proceedings of the Australia and New Zealand Academy Conference ANZMAC 2009, Melbourne, Australia, 1-6.

Singh, H. \& Dharamveer, Dr. (2011). Rebranding - A boon to survive, Indian Journal of Marketing, 41 (6), 55-60.

Stuart, H. and Muzellec, L. (2004). Corporate makeovers: Can a hyena be rebranded? Brand Management, Vol. 11 No. 6, pp. 472-482.

Teh, G. M. \& Salleh, A.H. M. (2011). Impact of brand meaning on brand equity of higher educational institutions in Malaysia, World Journal of Management, 3 (2), 218-228.

Walsh, M. F., Winterich, K. P \& Mittal, V. (2010). Do logo redesigns help or hurt your brand? The role of brand commitment, Journal of Product and Brand Management, 19 (2), 76-84. http://dx.doi.org/10.1108/10610421011033421.

Washburn, J. H. \& Plank, R. E. (2002). Measuring brand equity: An evaluation of a consumer based brand equity scale, Journal of Marketing Theory and Practice, 10 (1), 46-62.

Yoo, B. \& Donthu, N. (2001). Developing and validating a multidimensional consumer-based brand equity scale, Journal of Business Research, 52 (1), 1-14.

\section{Copyright Disclaimer}

Copyright reserved by the author(s).

This article is an open-access article distributed under the terms and conditions of the Creative Commons Attribution license (http://creativecommons.org/licenses/by/3.0/). 